\title{
Regulering - en innledning
}

\author{
Av Paul Larsson ${ }^{l}$
}

I 1985 utga Stanley Cohen boken »Visions of social control«. Her beskriver Cohen utviklingstrekk innen den formelle sosiale kontrollen i samfunnet. Sosial kontroll, et meget vidt begrep beskriver han slik: "... sosial kontroll er den organiserte måten samfunnet reagerer på atferd og folk som det oppfatter som avvikende, problematisk, uroende, truende, vanskelige eller uønskede på et eller annet vis«. (Cohen 1985 s. 1)

Cohen tegner et dystert bilde av utviklingen. Kontrollen øker, blir ganske altomfavnende, flere og flere havner i det vidtfavnende nettet. Stadig mindre avvik fanges opp av et økende utbud av profesjonelle hjelpere og kontrollører. Definisjonen av normalitet snevres inn, antall diagnoser øker og kontrollprofesjonene fanger opp stadig flere som antas trenge hjelp, behandling eller straff. Eller både hjelp, behandling og straff. Samtidig vokser fangepopulasjonen, til tross for at antall alternative sanksjonsformer og forebyggende tiltak også øker (Christie 1993).

Et par tiår senere er mye av perspektivet dreiet over mot sikkerhet og trygghet. Staten har tatt en annen rolle, mye av den samfunnsmessige kontrollen er solgt ut til en rekke, særlig private aktører (Johnston og Shearing 2003). Statens har tatt et skritt tilbake, hvor de fører tilsyn og forsøker styre de som utøver kontrollen. Begrepet governing, på norsk styring, er mer sentralt. Det er ikke noen direkte motsetning mellom Cohens og senere Shearings perspektiver, men statens rolle er mer indirekte, det private langt mer sentralt og siktepunktet har gått fra et fokus på kriminalitet og straff over til styring, risiko, forebygging og trygghet.

Innen studier av kontrollen av økonomisk kriminalitet har begrepet regulering blitt sentralt (Larsson 2011, Clarke 2000, Ayres og Braithwaite 1992). Regulering sikter til former for formell sosial kontroll som vektlegger å utvikle et regelverk og å opprette kontrollører for å iverksette reguleringen. Det meste av reguleringen sikter mot å utvikle måter å forhindre at uønsket atferd oppstår. Det skjer ofte ved at det utvikles standarder og gjennom samarbeid med de som reguleres. Compliance er en sentral term som i praksis betyr at bedrifter og andre selv må se til at regelverk iverksettes og følges opp. Hovedtyngden innen kontrollen ligger på selvregulering.

Clarke har følgende definisjon av regulering: 
»Vi kan si at regulering inneholder dannelsen av en form for autoritet, enten internt eller eksternt, for å oppnå orden innen et område av livet man har blitt oppmerksom på som viser tegn til utvikling av uorden, eksesser og fordervelse. Vellykket regulering innebærer enighet fra de regulerte og derfor er mye aktivitet rettet mot å oppnå og ofte å heve standarder.« (Clarke $2000 \mathrm{~s}$. 3)

Kontrollen med at det omfattende regelverket følges opp skjer i stor grad av et bredt spekter av ulike administrative myndigheter og tilsyn (Larsson 2002, Alalehto her). Politiets rolle er i liten grad som førstelinjekontrollører, men mer som mottakere av anmeldelser eller tips fra næringslivet og de ulike myndighetene.

Bidragene i denne samlingen tar opp en rekke grunnleggende spørsmål vedrørende denne utviklingen. Flere, Korsell, Alalehto og Träskman, tar opp historikken bak det kriminalpolitiske fokus på økonomisk og organisert kriminalitet. Utviklingen innen den moderne globale økonomi har medført en enorm vekst innen handel, som Christophersen dokumenterer. Kompleksiteten i den moderne økonomi og i næringslivet har økt betydelig i løpet av kort tid. Tidligere kunne man langt på vei basere mye av den økonomiske samhandelen på relativt enkle metoder, fordi man ofte hadde relasjoner og varige forbindelser med samhandlingspartnere. Dagens system er i langt større grad basert på abstrakte ikke-personlige tillitsforhold og tidsmessig avgrensede relasjoner (Giddens 1990). Dette medfører øt behov for regelverk og formalisering av kontrollen.

Den moderne økonomi er, som man så tydelig ser i dagens situasjon, sårbar. Reguleringssamfunnet har vokst frem hånd $\mathrm{i}$ hånd med en opptatthet av risiko og sikkerhet. Dette henger sammen med det store potensialet for ulykker og katastrofer som finnes innen moderne industri, transport og kommunikasjon. Samtidig har det blitt enklere rent teknisk å utøve alvorlige forbrytelser som terror eller omfattende økonomisk eller organisert kriminalitet. Skadepotensialet er omfattende.

Reguleringen har få̊t $\sin$ form av noen enkle forhold. En omfattende regulering av næringslivet er nødt til å hvile på en viss grad av samarbeid for å fungere. Selvregulering kan være en effektiv måte å kontrollere næringer og bedrifter på, men kan også svikte om det ikke følges opp fra myndighetshold, som Larsson og Sørli og Christophersen viser. Staten har rett og slett ikke muligheter eller kapasitet til selv å utføre direkte overvåkning og kontroll av næringslivet. Dessuten vil direkte overvåkning og kontroll oppfattes som uønsket og unødvendig. Prisen rent økonomisk for dette ville dessuten bli for høy.

Det er en politisk styrt utvikling, noe Träskman og Korsell på ulikt vis tar opp. Selvregulering av næringslivet passer godt med rådende styringsideologi og mar- 
kedsfokus. Det kan selges inn som deregulering og markedstilpasning, mens det i praksis har vist seg å være re- og omregulering i stor skala. Den store bevegelsen har ofte vært fra statlig rammeregulering av næringer og økonomien over til detaljregulering av den »frie « konkurransen.

Man kan kanskje få en følelse av at Cohens kontrollsamfunn har sneket seg inn bakdøren via reguleringen av næringslivet. At man her har opprettet et finmasket, altomfattende kontrollnettverk som fanger opp selv relativt små avvik innen næringslivet. I denne sammenhengen er det nok å lese Ollu og Alvesalos bidrag om trafficking og arbeidsutnyttelse, eller Christophersens om manglende oppfølging og implementering av regleverk innen havnekontroll og skipsfart eller Larsson og Sørlis studie av taxinæringen for å se at det ikke er nok med et omfattende regelverk for å forhindre lovbrudd og problemer. Lærdommen er klar; det er ikke regelverket som mangler, det er implementeringen og bruken av det $\mathrm{i}$ praksis, kanskje også viljen som her svikter.

Ved lesing av bidragene i denne samlingen, hvor ulike de enn er, kan man se noen store trekk innen utviklingen av reguleringen.

Omfattende reguleringspotensial betyr ikke det samme som god kontroll. At det finnes et regleverk som er ratifisert, at det finnes lover som truer med sanksjoner ved brudd betyr ikke nødvendigvis at man har gjort noe grunnleggende med problemene. Ollus og Alvesalo spør hvorfor det gjøres så lite med problemene forbundet med utbytting og overgrep mot arbeidere som er offer for trafficking. Det synes som disse lovbruddene har noen trekk som gjør at de ikke møtes med unison reaksjon. Overgrepene vekker ambivalente reaksjoner, ofrene fremstår som tvetydige, de kan som potensielle innvandrere virke truende. Noen arbeidere er mer attraktive enn andre, man vil ha de »nyttige«, ressurssterke og riktige, ikke de fattige og utbyttede. Dessuten må et regelverk iverksettes i praksis og følges opp med riktige tiltak om det skal ha noen mulighet for å fungere. Noe av regelverket kan nærmest se ut som symbolsk lovgiving. Christophersen belyser problemstillingen opp mot maritim sikkerhet hvor skadepotensialet er omfattende, men norske myndigheter likevel ikke synes å ha oppfylt grunnleggende forpliktelser. Taxinæringen har de siste tiårene vært en gjenganger når det gjelder skatteunndragelser. Problemene med omfattende svart kjøring har vært kjent og forsøkt regulert, i alle fall siden slutten av 80 - tallet. Likevel fikk vi nylig en av de absolutt største skatteunndragelsessakene i norsk historie innen næringen. Larsson og Sørli viser at det ikke har vært mangel på regelverk og krav til næringen eller kunnskap hos kontrolletatene som har vært problemet. Den svarte aktiviteten synes å sitte godt fundert i grunnleggende strukturer innen næringen, i den konkrete skattesaken godt hjulpet av eksperter som har utviklet systematiske opplegg 
for å unndra midler. Man kan spørre hvorfor ikke dette ble stanset tidligere, når signalene var tydelige. Et svar på dette handler om at overvåkningen, i dette tilfellet gjennom skattemyndighetene må være selektiv. Ofte skal det ofte omfattende overtramp til før myndighetene setter inn ressurser på å følge dette opp.

Reguleringen og regelverket internasjonaliseres. De utviklingstrekk som en rekke av bidragene peker ut, kanskje mest tydelig hos Christophersen, er betydningen av utviklingen av internasjonale regelverk og kontrollregimer. Nasjonalstater er ikke frie til å gjøre som de vil når det gjelder ratifisering og implementering av regleverk. Det finnes en rekke overnasjonale tilsynsorganer, ESA er et som nevnes, som utøver tilsyn og som kan sanksjonere brudd på regelverk. Sanksjonene kan i praksis være strenge, FATF - Financial Action Task Force - kan svarteliste land som ikke følger opp det etter hvert omfattende og komplekse regleverket som gjelder hvitvasking. Det kan være ødeleggende for næringslivet og påvirke økonomien, en konsekvens Christophersen nevner. En side ved dette er at man derved importerer regelverk som kan oppleves som både fremmed og tidvis noe overdrevet i forhold til de nasjonale realiteter. Regelverket stiller vanligvis også ganske konkrete krav, eksempelvis til sikring av havneområder eller overvåkningsutrustning og systemer, som igjen påvirker samfunnslivet.

Grenser viskes ut. Flere av bidragene er inne på hvordan grensene mellom økonomisk og organisert kriminalitet og terror i dag viskes ut innen reguleringen og kriminalpolitikken. Träskman dokumenterer dette og spør om det er slik at det gamle skiller mellom organisert og økonomisk kriminalitet har blitt mindre synlig og om man finner empirisk belegg for at det er slik at terror og økonomisk kriminalitet er sammenkoblet. På det første spørsmålet svarer han langt på vei ja; dagens virkelighet når det gjelder skillet mellom økonomisk og organisert kriminalitet er at det langt på vei har blitt mindre tydelig at økonomisk kriminalitet er »lovbrudd begått i forbindelse med ellers legal virksomhet«. En vesentlig virksomhet for mange organiserte nettverk i dag er økonomisk kriminalitet, eksempelvis ved subsidiesvindel eller karusellhandel. På den annen side finner han koblingen mellom terror og økonomisk kriminalitet langt svakere. Träskman trekker frem de politiske aspektene ved dagens fokus på alvorlig kriminalitet, terror og organisert kriminalitet, at det er »skrekk lovbrytere« som kan benyttes kriminalpolitisk for å få innført bruk av tøffere metoder og strengere sanksjoner.

Korsell behandler utglidingen i bruk av etterforskningsmetoder som har skjedd, særlig i forhold til organisert og økonomisk kriminalitet. Metoder som avlytning og bruk av etterretning, som tidligere ble ansett særskilt godt egnet mot såkalt alvorlig organisert kriminalitet, benyttes nå innen økonomiske saker. Metoder som før hovedsakelig ble benyttet mot økonomisk kriminalitet, som revisor- 
innsats mot pengebevegelser er nå sentrale i innsatsen mot både organisert kriminalitet og terror. Denne formen for utgliding innen bruk av politi- og kontrollmetoder er velkjent fra kriminologiske og rettssosiologiske studier, blant annet ofte advart mot av Thomas Mathiesen. På denne måte utviskes også tradisjonelle skillelinjer mellom forebygging og reaktivt politiarbeid. I dag arbeider man med »å bygge saker« mot de nevnte formene for kriminalitet. Det vil si man bygger på etterretningskunnskap og rettet innsats mot kjente grupper og miljøer som man mistenker å planlegge eller kunne utføre lovbrudd. Den tilnærming som har kommet å kjennetegne mye av arbeidet innen økonomisk og organisert kriminalitet er hva Brodeur (2010) betegner som »high policing«. I motsetning til polisiær virksomhet rettet mot tradisjonell kriminalitet hvor man venter på at lovbrudd skal begås og siden går inn med åpen etterforskning så er dette arbeidet preget av bruk av skjulte kilder, at man »bygger saker « ofte etter tips, etterretning og informanter, ikke-uniformert innsats og mangel på åpenhet innen politiet. Mye av denne tilnæringen kommer opprinnelig fra bekjempelsen av terror og politisk overvåkning.

Et annet trekk som også er tydelig i flere av bidragene er betydningen av samarbeid på tvers av ulike myndigheter. I dag har en rekke tilsyn og myndigheter viktige oppgaver innen reguleringen av økonomisk kriminalitet, men det stanser ikke der, også en rekke private aktører er sentrale. Det kan dreie seg om revisjonsfirmaer som har spesialisert seg på forensic accounting, det kan også være bedriftene selv eller bransjeorganisasjoner som Larsson og Sørli påpeker.

En side av de utviklingstrekk som er beskrevet er at strafferetten relativt taper terreng som regulerings eller kontroll paradigme. Langt på vei blir trusselen med straff det ytterste man kan iverksette, selv om mye tyder på at flere former for administrative sanksjoner, som å trekke tillatelser, kan oppleves som langt verre for bedriftene. Det viktigste innen kontrollen skjer i og av bedriftene, ofte i sikkerhetsavdelinger, eller av andre private aktører som betales for å overvåke og kontrollere deler av driften og at regelverk overholdes. Det har vokst frem egne profesjoner som er eksperter på compliance, mye av ansvaret for at regelverket overholdes i store bedrifter kan være solgt ut til profesjonelle, det har blitt en vare. De fleste større revisjonsfirmaer leverer i dag et bredt utbud av tjenester, blant annet såkalt forensic accounting, slik at brudd på regleverk som oppdages langt på vei kan håndteres uten å måtte benytte offentlige tjenestemenn i det hele tatt. 


\section{Note}

1. Paul Larsson er professor i kriminologi ved Politihøgskolen i Oslo og gjesteprofessor i Politivitenskap ved Linnéuniversitetet i Växjö. Han var tidligere stipendiat ved Institutt for kriminologi og seksjonssjef for analyse og forebygging i Politidirektoratet. Publikasjoner dekker feltene økonomisk og organisert kriminalitet, kriminologisk teori og studier av politi.

\section{Referanser}

Ayres, Ian \& Braithwaite, John (1992): Response Regulation. Transcending the Deregulation Debate, Oxford Socio - Legal Studies, Oxford.

Broduer, Jean-Paul (2010): The Policing Web, Oxford University Press, Oxford.

Christie, Nils (1993): Kriminalitetskontroll som industri. Universitetsforlaget, Oslo.

Clarke, Michael (2000): Regulation. The Social Control of Business between Law and Politics, MacMillan Press, Houndmills.

Cohen, Stanley (1985): Visions of social control, Polity Press, Cambridge.

Giddens, Anthony (1990): The Consequences of Modernity, Stanford University Press, Stanford.

Johnston, Les og Clifford Shearing (2003): Governing Security. Explorations in Policing and Justice, Routledge, London.

Larsson, Paul (2002): A straffe, veilede eller overtale, Kråd rapport. Oslo.

Larsson, Paul (2011): »Det farlige næringslivet. Reguleringen av økonomisk kriminalitet i det 21. århundre«, i Alalehto og Larsson (red.): Vinddriven kriminalitet på en vinddriven marknad. Ekonomisk och organiserad brottslighet, Recito förlag, Borås. 